To Maega | Jurnal Pengabdian Masyarakat

Februari 2021, Vol.4, No.1, hal, 35-46

$\operatorname{ISSN}(P): 2622-6332 ; \operatorname{ISSN}(E): 2622-6340$

http://www.ojs.unanda.ac.id/index.php/tomaega

\title{
Ekonomi Kreatif Sebagai Solusi Bagi Keluarga Pra Sejahtera Untuk Bertahan Dalam Era New Normal
}

\author{
Yohan Fitriadi ${ }^{1}{ }^{*}$, Wellia Novita ${ }^{1}$, Devi Edriani ${ }^{1}$ \\ ${ }^{1}$ Fakultas Ekonomi Dan Bisnis, UPI YPTK Padang
}

*Correspondent Email: yohan.ftr@gmail.com

Article History:

Received: 05-10-2020; Received in Revised: 5-11-2020; Accepted: 3-12-2020

DOI: http://dx.doi.org/10.35914/tomaega.v4i1.473

\begin{abstract}
Abstrak
Terjadinya pandemi virus covid-19 menyebabkan peran keluarga semakin penting dalam rangka mencegah penularan pandemi Covid-19. Keluarga menjadi harapan untuk pencegahan pandemi covid dengan tetap berada di rumah, membimbing anak untuk tetap belajar di rumah. Oleh sebab itu team PKM UPI YPTK pun mencoba menawarkan solusi kepada keluarga Pra sejahtera untuk mencari solusi lain dalam rangka mendapatkan pemasukan tambahan walau tetap berada di rumah. Metode pelaksanaan kegiatan pengabdian ini dilaksanakan mulai dari identifikasi mitra, kesepakatan penentuan objek pelatihan, pelatihan dan pendampingan, dan evaluasi bersama. Hasil yang didapatkan dari kegiatan tersebut adanya pemahaman, dan motivasi untuk memanfaatkan Ekonomi Kreatif bagi keluarga Pra Sejahtera sebagai kegiatan tambahan dalam mendapatkan pemasukan tambahan bagi keluarga. Kesimpulan dari kegiatan pengabdian tersebut diantaranya (1)Semua peserta bersemangat untuk mencari tahu kegiatan ekonomi lain, walau tetap berada di rumah (2) Dukungan dari Pemerintah terkait peningkatan ekonomi kreatif bagi keluarga Pra sejahtera perlu digalakan agar masyarakat pra sejahtera bisa meningkatkan ekonomi walau dalam keadaaan krisis
\end{abstract}

Kata Kunci: Permbedayaan, Keluarga, Produktivitas, Ekonomi Kreatif, UMKM,

Abstract

The occurrence of the covid-19 virus pandemic has made the role of the family increasingly important in order to prevent the transmission of the Covid-19 pandemic.. Families become hope for the prevention of the Covid pandemic by staying at home, guiding children to keep studying at home. Therefore, the UPI YPTK PKM team also tried to offer a solution to the Pra-prosperous family to find other solutions in order to get additional income even though they were still at home. The method of implementing this service activity is carried out starting from partner identification, agreement on determining training objects, training and mentoring, and joint evaluation. The results obtained from these activities were understanding, knowledge and motivation to take advantage of the Creative Economy for poor families as an additional activity in getting additional income for the family. The conclusions of these service activities include (1) All participants are eager to find out other economic activities, even though they are still at home (2) Support from the Government related to increasing the creative economy for the Pra-prosperous family, it needs to be encouraged so that the pre-prosperous community can improve the economy even in a state of crisis

Key Word: Empowerment, Family, Productivity, Creative Economy, UMKM, 


\section{Pendahuluan}

Pada pertengahan bulan Maret, di Indonesia tengah dihebohkan oleh berita Corona Virus Disease tahun 2019 yang dikenal dengan Covid-19. Covid-19 adalah penyakit menular yang disebabkan oleh virus corona baru. Wabah infeksi Covid-19 merupakan sindrom pernafasan akut yang parah pertama kali dilaporkan terjadi di Wuhan, China, dan menyebar ke seluruh China dan sekitarnya ( $\mathrm{Zu}$ et al., 2020). Virus ini mengakibatkan segala aktivitas yang dilakukan oleh semua orang menjadi terhambat. Orang-orang yang bekerja dianjurkan WFH (Work From Home), siswa sekolah maupun mahasiswa juga dianjurkan belajar dirumah. Menurut data BPS, dampak dari Covid-19, penduduk miskin naik Jadi 26,42 juta orang (Lentera, 2020). Ekonomi di Indonesia khususnya di Kota Padang mengalami penurunan akibat Covid-19 tersebut.

Padahal pemerintah awalnya menargetkan pencapaian pertumbuhan ekonomi sebesar 5-5,4 persen. Bahkan diharapkan Indonesia dapat menjadi salah satu negara dengan berpendapatan high middle income country. Dilansir dari Kontan.co.id pada 19 Maret 2020, Di tengah merebaknya Covid-19, Bank Indonesia (BI) merevisi proyeksi pertumbuhan ekonomi Indonesia 2020 menjadi 4,2\%-4,6\%. Dari berbagai upaya yang dirumuskan dalam pencapaian pertumbuhan ekonomi sebesar 4,6 tersebut, maka pemerintah perlu mengambil langkah yang paling efektif untuk menjaga agar perekonomian Indonesia bisa tetap stabil (Yenti, 2020).

Di negara-negara maju juga mulai menyadari bahwa saat ini mereka tidak bisa hanya mengandalkan bidang industri sebagai sumber ekonomi di negaranya tetapi mereka harus lebih mengandalkan sumber daya manusia yang kreatif karena kreativitas manusia itu berasal dari daya pikirnya yang menjadi modal dasar untuk menciptakan inovasi dalam menghadapi daya saing atau kompetisi pasar yang semakin besar. Pada tahun 1990-an dimulailah era ekonomi baru yang mengutamakan informasi dan kreativitas dan populer dengan sebutan ekonomi kreatif yang digerakkan oleh sektor industri yang disebut industri kreatif (Kamil, 2015).

Sistem ekonomi kreatif diyakini dapat dijadikan solusi dalam mengatasi masalah tersebut, Indonesia yang kaya akan budaya dan berpenduduk besar mempunyai potensi yang sangat besar dalam pengembangan ekonomi kreatif. 
Alvin Toffler dalam teorinya telah melakukan pembagian gelombang peradaban ekonomi kedalam tiga gelombang. Pertama, gelombang ekonomi pertanian. Kedua, gelombang ekonomi industri. Ketiga, gelombang ekonomi informasi. Berdasarkan prediksi, selanjutnya akan datang gelombang keempat, yaitu gelombang ekonomi kreatif dengan berorientasi pada ide dan gagasan kreatif (Pantzar, 2010).

Pengembangan Ekonomi Kreatif Indonesia merupakan wujud optimisme serta luapan aspirasi untuk mendukung mewujudkan visi Indonesia yaitu menjadi Negara yang maju. Didalamnya terdapat pemikiran, cita-cita, imajinasi, dan mimpi untuk menjadi masyarakat dengan kualitas hidup yang tinggi, sejahtera, dan kreatif (Fajariana \& Untari, 2019)

Ekonomi kreatif menjadikan setiap individu mengembangkan produk yang berawal dari gagasan, ide dan pemikiran. Diharapkan setiap individu menjadikan sesuatu menjadi barang yang bernilai ekonomis dan berdaya jual. Profesi yang mengaharuskan. Maka pengembangan ekonomi kreatif ini secara tidak langsung menciptakan wirausaha-wirausaha (entrepreneur) yang handal dalam berbagai bidang. Setiap kreativitas harus dilandasi oleh gagasan yang kreatif, berpikiran maju, penuh dengan Inovasi baru yang berbeda dengan yang sudah ada.

Kurangnya pemahaman dan kesadaran untuk menghasilkan suatu produk yang dilahirkan dari kreativitas serta inovasi, menyebabkan banyaknya potensi yang tidak terolah maksimal. Dengan inovasi ekonomi tersebut berefek bertambannya pendapatan keluarga. Inovasi selalu membawa perkembangan dan perubahan ekonomi. Inovasi bukan hanya suatu temuan yang luar biasa, tetapi suatu temuan yang menyebabkan berdayagunanya sumber ekonomi ke arah yang lebih produktif (Intisari \& Rosnina, 2019).

Peluang pengembangan ekonomi kreatif harus menyentuh segala aspek termasuk masyarakat Pra Sejatera. Ditambah dalam kondisi pandemi Covid-19 yang terjadi hari ini, diperlukan inisiatif dari masyarakat untuk melakukan inovasi dan kreatifitas agar tetap mendapatkan pemasukan tambahan dalam menutupi kebutuhan rumah tangga. Apalagi dengan kebijakan pemerintah untuk mengharapkan masyarakat yang bekerja atau beraktivitas dirumah saja. Erric Kondoy dalam penelitiannya pada warga di perumahan karisma kota Manado 
melihat seberapa besar peluang usaha kuliner rumahan. Kesimpulan dari penelitian tersebut menjelaskan bahwa usaha kuliner rumahan sangat membantu masyarakat untuk menutupi kebutuhannya pada masa pandemi Covid 19. Baik dari sisi masyarakat yang bertindak sebagai penjual yang memproduksi kebutuhan rumah tangga seperti makanan, kebutuhan yang lain ditengah krisis covid 19 (Kondoy \& Rahman, 2020)

Mengacu pada analisis situasi, dapat dilihat permasalahan pada keluarga Pra sejahtera di Kota Padang meliputi beberapa hal berikut; (1) Keluarga Pra sejahtera yang ada di Kota Padang sudah memiliki usaha yang berkaitan dengan sektor ekonomi kreatif, namun belum berkembang dan diperlukan pendampingan untuk pengembangan usaha tersebut (2) Masih minimnya pengetahuan dan metode untuk memasarkan hasil usaha, jika keluarga tersebut menciptakan kreatifitas ekonomi yang memiliki nilai jual ekonomis

Adapun solusi yang bisa diterapkan dalam waktu singkat yaitu, memberikan pelatihan kepada keluarga pra sejahtera yang ada di Kota padang untuk termotivasi dan memiliki harapan baru untuk menggeluti usaha kreatif walaupun beraktifitas di rumah. Sebagai Makhluk ciptakaan Allah, manusia tidak akan bisa melanjutkan hidup tanpa adanya harapan.(Mihaly Csikszentmihalyi, 2007) Untuk membangkitakan harapan masyarakat agar tidak putus asa dalam menggali kreatifitas adalah tujuan dari Pengabdian Kepada Masyarakat ini dilakukan.

Selanjutnya agar kegiatan tersebut memiliki dampak, perlu dilaksanakan kegiatan pendampingan serta mentoring agar kegiatan pemberdayaan ekonomi tersebut mampu dirasakan oleh keluarga pra sejahtera dalam mendapatkan tambahan dari aktifitas ekonomi dari rumah.

\section{Metode}

Berdasarkan uraian sebelumnya, serta hasil diskusi dengan mitra, maka prioritas permasalah yang harus diselesaikan bersama dengan mitra adalah memperkenalkan pengetahuan tentang ekonomi kreatif kepada keluarga Pra sejahtera, mulai dari contoh, metode kegiatan serta teknis operasional untuk menerapkan produktifitas ekonomi yang berbasikan ekonomi kreatif dalam rumah tangga. Oleh sebab itu perlu adanya pelatihan dan pendampingan tentang ekonomi kreatif bagi keluarga Pra sejahtera yang tersebar di beberapa kelurahan di Kota 
Padang. Team PKM telah melakukan survey dan memilih 3 kelompok masayarakat yang tergabung dalam keluarga Pra sejahtera yang berhimpun dalam kegiatan Program keluarga harapan. kelurahan yang dijadikan sampel pada kegiatan tersebut yaitu kelurahan Air Manis Padang Selatan sebanyak 15 Perwakilan keluarga Pra Sejahtera, kelurahan Ulak Karang selatan sebanyak 40 Perwakilan keluarga Pra Sejahtera Kecamatan Padang utara serta kelurahan Purus Padang Barat sebanyak 10 Orang Perwakilan keluarga Pra sejahtera. Maka Total partisipan yang mengikuti kegiatan PKM sebanyak 65 Perwakilan keluarga yang tersebar di 3 Kecamatan di Kota Padang.

Dalam pelaksanaan kegiatan prosedur kerja yang dilaksanakan dijelaskan sebagai berikut: (1) Melakukan rapat koordinasi bersama Tim PKM UPI YPTK Padang dalam waktu yang terukur dan tersistem. (2) Memilih tema dan kebijakankebijakan penting terkait kegiatan.(3) Melakukan survey lokasi kegiatan. (4) Kegiatan ini dilanjutkan dengan membuat kerjasama berupa penganggendaan jadwal kegiatan pengenalan ekonomi Kreatif. (5) Kegiatan selanjutnya adalah pelaksanaan kegiatan pelatihan dan pendampingan tentang ekonomi kreatif kepada keluarga sejahtera di Kota Padang yang telah diagendakan dalam pelaksanaan kegiatan tersebut. Agar seluruh kegiatan memiliki Data administrasi team PKM Mendata dengan baik seluruh peserta kegiatan dan fasilitas yang digunakan selama berkegiatan pengenalan ekonomi kreatif.

Dalam kegiatan pengabdian kepada masyarakat ini cara yang digunakan adalah memberi informasi mengenai kegiatan pengenalan ekonomi kreatif kepada Masyarakat Pra Sejahtera serta mengaplikasikan konsep-konsep tersebut dengan menciptakan ekonomi kreatif sesuai dengan bakat dan minat Masyarakat Pra Sejahtera. Sehingga hal ini dapat mendorong anak-anak melaksanakan kegiatan ini dengan sangat baik dan optimal untuk mencapai hasil yang maksimal. Implementasi kegiatan dapat diuraikan sebagai berikut: 


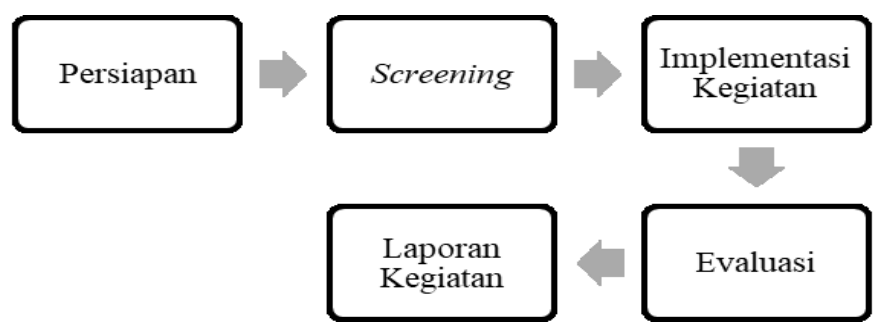

Gambar 1. Metode Pelaksanaan pengabdian Kepada Masyarakat Pada Keluarga Pra Sejahtera di Kota Padang

Pada tahapan Persiapan dari kegiatan ini mencakup beberapa prosedur: mulai dari Menyiapkan materi, melakukan Survei lokasi, Membuat proposal dan proses persetujuan lokasi pengabdian kepada masyarakat. Selanjutnya pada tahapan Screening mulai dari Menyiapkan pembicara dan panitia sebelum acara, Memastikan semua alat-alat siap dibawa ke lokasi, Memastikan semua kebutuhan acara seperti Alat tulis, Proyektor serta Spanduk telah tersedia.

Pada Implementasi kegiatan mancakup prosedur teknis pelaksanaan kegiatan meliputi Pemberian materi mengenai tata cara dan strategi dalam pengenalan serta menciptakan ekonomi kreatif bagi keluarga Pra sejahtera yang ada di Kota Padang. Kemudian Memberi informasi mengenai ekonomi kreatif dan manfaat dari ekonomi kreatif bagi Masyarakat Pra Sejahtera yang ada di Kota Padang. Selanjutnya mempraktekkan sebuah bentuk ekonomi kreatif terhadap Masyarakat Pra Sejahtera tersebut, sehingga nantinya akan menciptakan suatu produk yang siap untuk di pasarkan kepada masyarakat banyak, Khususnya masyarakat yang ada di sekitar.

Tahapan terakhir adalah evaluasi. Sebuah pelatihan yang sukses adalah pelatihan yang tidak hanya baik dalam pelaksanaan, tetapi juga mampu memenuhi tujuannya yaitu memperbaiki atau meningkatkan performa dari pesertanya. Untuk menilai keberhasilan program kegiatan ini team PKM UPI YPTK melakukan dengan cara melakukan mengevaluasi dengan model evaluasi summative, dimana pelatihan tersebut hanya melihat dan memperhatikan antara tujuan yang ingin dicapai dan hasil yang tercapai (Prasetyo et al., 2014).

Dari evaluasi yang diamati selama pelatihan $85 \%$ Peserta yang diundang hadir dalam pengenalan dan pelatihan ini antusias dalam mengikuti kegiatan. Selanjutnya $20 \%$ Peserta yang diberikan pelatihan selanjutnya berfikir 
mengembangkan ekonomi kreatif sesuai dengan minat dan bakat mereka. Hal ini dilihat dari Pernyataan kepuasan dari Peserta setelah sosialisasi dan pelatihan. Terakhir tahapan yang dilakukan oleh team PKM UPI YPTK adalah membuat Laporan kegiatan. Laporan kegiatan disusun oleh Tim PKM Mandiri UPI YPTK Padang setelah kegiatan selesai dilaksanakan. Laporan kegiatan kemudian diserahkan kepada LPPM UPI YPTK Padang.

\section{Hasil dan Pembahasan}

Kegiatan PKM dengan tema ekonomi kreatif sebagai solusi bagi keluarga pra sejahtera untuk bertahan dalam era new normal dilaksanakan pada tanggal 23 dan 26 Agustus 2020. Kegiatan tersebut telah dilaksanakan di tiga kecamatan di Kota Padang yaitu Kecamatan Padang Utara, Padang Barat dan Padang Selatan. Peserta yang telah mengikuti kegiatan ini sebanyak 65 Orang yang merupakan masyarakat binaan dinas sosial Kota padang pada Program Keluarga Harapan.

Masyarakat yang tergabung dalam binaan Program Keluarga harapan adalah keluarga yang memiliki ekonomi dengan tingkat rentan miskin. Dalam keadaan pandemi seperti yang terjadi di tahun ini, masyarakat dengan ekonomi menengah ke bawah tentu merasakan dampak langsung maupun tidak langsung seperti pemutusan hubungan kerja dengan adanya pandemi Covid-19 (Putri et al., 2020). Rata-rata pekerjaan keluarga yang berada pada ekonomi lemah dan Pra sejahtera adalah aktifitas yang dilakukan di luar rumah, seperti Buruh Pabrik, Tukang Ojek, Cleaning Service, Satpam dan usaha keliling. Meraka tidak akan mendapatkan pemasukan jika pekerjaan mereka lakukan di rumah.

Pada kegiatan pelatihan yang dilaksanakan oleh team PKM UPI YPTK materi yang dipaparkan terlebih dahulu mengulas tentang dampak pandemi Covid-19. Per Agustus 2020 (Pada saat pelaksanaan kegiatan) di Kota Padang telah terdapat pasien positif Covid-19 sebanyak 863. Hingga artikel ini ditulis pada 3 Oktober terdapat kasus positif Covid-19 di Kota padang sebanyak 3.330 kasus.

Beberapa catatan yang disampaikan oleh team Pelatihan pada kegiatan tersebut terkait dengan penyebaran Covid-19 adalah dikutip dari katadata.co.id pada 4 Agustus 2020, Juru bicara Satuan Tugas Penangananan Covid-19 Wiku 
Adisasmito tak bisa memprediksi akhir dari pandemi Covid-19. Kemudian Vaksin dan obat untuk asih belum ditemukan hingga saat ini.

Kemudian dengan ekonomi yang berada pada fase krisis menyebabkan Indonesia berada di ambang resesi Di sektor ekonomi. Laporan berbagai lembaga internasional menunjukkan kontraksi ekonomi yang bisa memicu terjadinya resesi global (Winanti, 2020)

Informasi dampak pandemi Covid-19 yang diulas oleh tim PKM UPI YPTK kepada peserta kegiatan adalah hampir 1,9 Juta pekerja Formal dan Informal mengalami PKH semenjak Covid-19 diumukan menjadi problem baru bagi aktifitas ekonomi di Indonesia. Melalui data yang dilansir dari Kementerian Ketenagakerjaan (Kemnaker) per 19 April 2020 tercatat 1.943.916 tenaga kerja diberhentikan dari pekerjaan meraka. Maka dari beberapa masalah diatas sangat penting bagi keluarga untuk meningkatkan produktivitas ekonomi dalam rangka bertahan dalam era new normal Pandemi Covid-19.

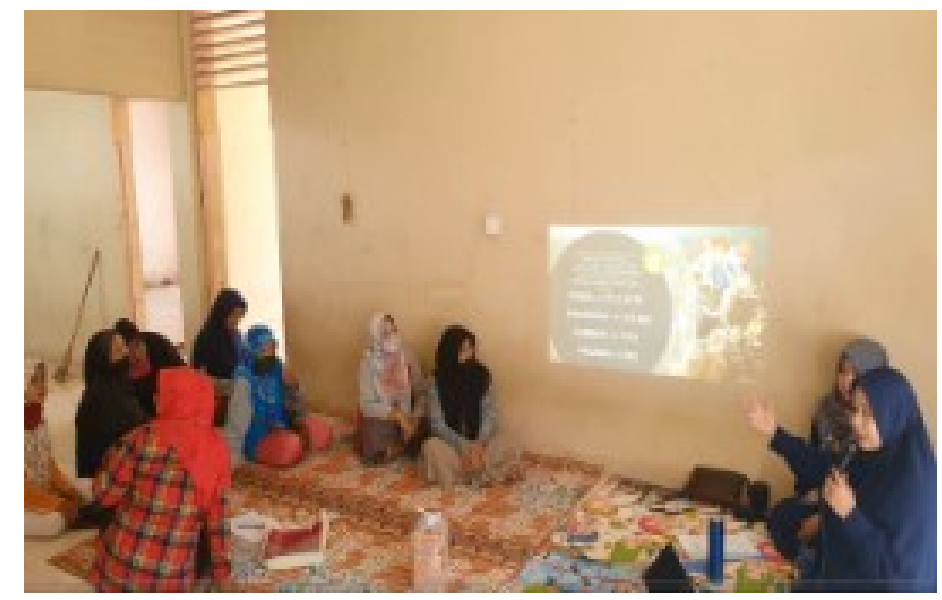

Gambar 2. Tim PKM UPI YPTK Mengulas Materi Kegiatan

Dalam pelatihan ini, tim PKM UPI YPTK juga mengulas cara untuk meningkatkan produktifitas ekonomi bagi keluarga Pra Sejahtera untuk bertahan di era krisis seperti yang terjadi hari ini adalah dengan memahami konsep ekonomi kreatif. Mayoritas peserta pelatihan yang hadir sejatinya sudah melaksanakan aktifitas ekonomi seperti membuat kerajinan dari barang bekas, produk kuliner tradisional dan kerajinan tangan lainnya. Namun aktifitas yang mereka lakoni sebatas untuk aktifitas perseorangan yang belum terkelola secara kelompok dan berkelanjutan. Dalam hal ini tim PKM pun mencoba untuk 
mengurai pemahaman tentang Ekonomi Kreatif pada peserta yang hadir mulai dari bentuk-bentuk Ekonomi kreatif, manfaat ekonomi kreatif serta Aktifitas Ekonomi Kreatif yang bisa dimanfaatkan di rumah tangga.

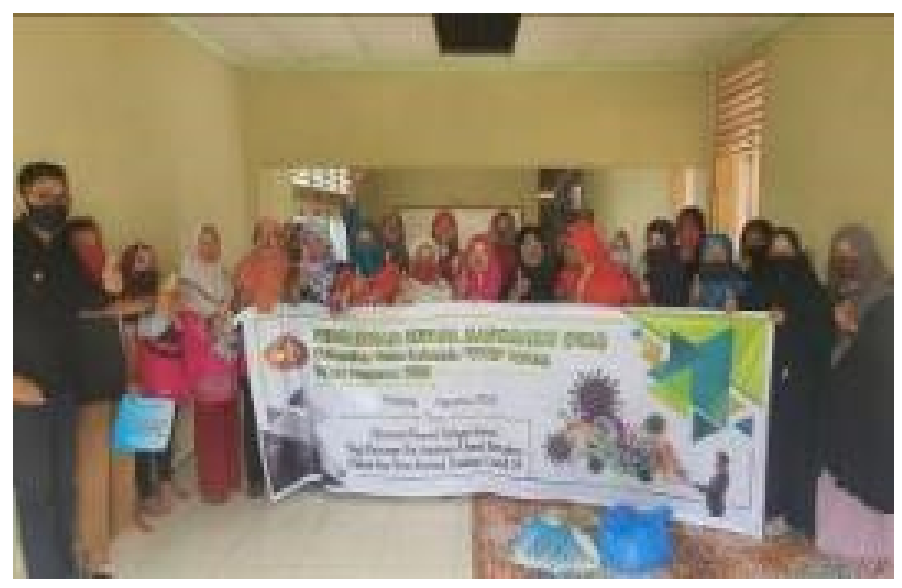

Gambar 3 Sesi Foto Bersama Dengan Peserta Pasca Pelaksanaan Pelatihan.

Dari hasil evaluasi, yang dilaksanakan antara tim dosen dan mitra, ada peningkatan pengetahuan dan motivasi mitra sebagai peserta pelatihan. Hal ini tampak dalam tabel berikut.

Tabel 1. Evaluasi Pelaksanaan Kesuksesan PKM.

\begin{tabular}{llll}
\hline No & Aspek yang dilihat & Indikator keberhasilan \\
\hline 1. & Pengetahuan & Ekonomi & Peserta Termotivasi untuk mencoba \\
& Kreatif & dalam & Peserta serius menyimak materi yang \\
& dipaparkan oleh tim PKM UPI YPTK \\
\hline 2. & Keseriusan & Pelatihan & Adanya pertanyaan-pertanyaan dari \\
& Feedback atas materi yang & peserta terkait penciptaan ekonomi \\
& disampaikan & kreatif yang bisa dilaksanakan dari rumah \\
& & mulai dari tahapan perancangan sampai \\
& & mekanisme penjualan \\
\hline 4 & Animo Peserta & Peserta mengikuti materi dari awal \\
& & hingga akhir dan meminta untuk adanya \\
& & lanjutan dari PKM tersebut
\end{tabular}

Beberapa kendala yang terjadi selama pelatihan adalah lokasi kegiatan yang tidak memungkinkan untuk memaparkan materi dengan media bantu proyektor. 
Hal ini disebabkan oleh lokasi kegiatan yang berpindah-pindah dan banyaknya peserta yang ingin mengikuti kegiatan tersebut. Tim PKM pun mengulas materi dengan metode ceramah dan tidak memungkinkan untuk memutar video bentukbentuk kreatifitas yang bernilai ekonomi dan dilaksanakan di rumah selama pandemi Covid-19.

Dengan adanya kegiatan pelatihan dari tim PKM UPI YPTK padang diperoleh pengetahuan baru oleh mitra terkait pemahaman ekonomi kreatif yang bisa membuat keluarga pra sejahtera mampu bertahan di krisis ekonomi akibat pandemi Covid-19. Begitu banyak peluang usaha di tengah wabah corona ini. Selain dari industri kerajinan rumah tangga, sebagian besar dari peserta yang mengikuti pelatihan sudah memiliki usaha kuliner yang semestinya perlu dilakukan inovasi untuk menarik minat konsumen (Rohmah \& Syari, 2020). Apalagi ditambah dengan adanya teknologi, pemasaran produk yang dihasilkan tidak saja hanya dipasarkan pada lingkungan sekitar, namun juga dapat dilirik oleh konsumen dari luar lingkungan dengan bantuan pemasaran dengan media sosial.

\section{Kesimpulan}

Dari rangkaian kegiatan program pengabdian kepada masyarakat yang dilakansakan oleh tim PKM UPI YPTK Padang didapatkan beberapa kesidmpulan diantaranya (1) Ancaman Pandemi Covid-19 sangat dirasakan oleh masyarakat ekonomi lemah dan pra sejahtera, mulai dari minimnya informasi tentang pandemi Covid-19 sampai dengan berkurangnya pendapatan akibat kelesuan ekonomi selama pandemi (2) Keluarga Pra sejahtera yang melaksanakan kegiatan pelatihan termotivasi untuk menggeluti usaha ekonomi kreatif berbasiskan rumah tangga dan mencari tahu informasi tersebut melalui media sosial dan internet (3) Sektor ekonomi kreatif yang mampu digeluti oleh rumah tangga diantaranya Usaha Kerajinan hand Made seperti pembuatan masker, Connecting mask, Souvenir pesta serta usaha kuliner kekinian maupun usaha kuliner tradisional

\section{Ucapan Terimakasih}

Ucapan terima kasih, ditujukan kepada; (1) Ketua Yayasan Perguruan Tinggi Komputer (YPTK) Padang, Bapak H. Herman Nawas dan Ibu Dr. Hj. 
Zerni Melmusi, MM, Ak, CA, yang telah membantu dalam support dan pembiayaan melalui dana hibah yayaysan dalam pelaksanaan kegiatan Pengabdian Kepada Masyarakat tahun 2020 (2) Rektor UPI YPTK Padang, Bapak Prof. DR. yang telah mendukungan penuh pada para dosen dalam melaksanakan Tri Dharma Perguruan Tinggi, dengan kebijakan-kebijakannya; (2) Dekan Fakultas Ekonomi dan Bisnis Dr. Elfiswandi, MM, Ak, CA yang telah memberikan dukungan dan stimulus positif untuk para dosen yang melaksanakan Tri Dharma Perguruan Tinggi; (3) Rekan_rekan dosen yang selalu saling mendukung dan mengingatkan dalam segi yang positif; (4) Koordinator Kecamatan, Pendamping PKH serta Ibu-ibu Keluarga Penerima Manfaat bantuan Program keluarga Harapan di Kota padang (6) Mahasiswa yang turut membantu kami dalam menyiapkan properti yang dibutuhkan oleh tim dosen FEB UPI YPTK Padang

\section{Daftar Pustaka}

Csikszentmihalyi, M. (2007). Good Business: Bisnis Sebagai Jalan Kebahagiaan. Bandung: Mizan Pustaka.

Fajariana, D. E., \& Untari, D. (2019). Peningkatan Pertumbuhan Ekonomi Melalui Wisata Kuliner Malam Gultik (Gulai Tikungan) Blok M Jakarta Selatan. Ekono Insentif, 13(1), 1-15.

Intisari, I., \& Rosnina, R. (2019). Pemberdayaan Masyarakat Melalui Pelatihan Berbagai Olahan Jantung Pisang Di Desa Pabbarasseng Kecamatan Bua Kabupaten Luwu. To Maega | Jurnal Pengabdian Masyarakat, 2(2), 58-62.

Kamil, A. (2015). Industri Kreatif Indonesia: Pendekatan Analisis Kinerja Industri. Media Trend, 10(2), 207-225.

Kondoy, E., \& Rahman, R. (2020). Peluang Usaha Kecil Kuliner Rumahan Masyarakat Perum Kharisma Koka Ditengah Pandemi Covid 19. JISIP (Jurnal Ilmu Sosial Dan Pendidikan), 4(3).

Harian Lentera. (2020). DUH , ORANG MISKIN RI Bengkak jadi 26, 42 Juta.Terbit 16 Juli 2020.

https://nasional.kontan.co.id/news/corona-bi-pangkas-proyeksi-pertumbuhanekonomi-indonesia-jadi-42-46

Pantzar, M. (2010). Future Shock - Discussing the Changing Temporal Architecture of Daily Life 1. 14(June 2010), Jurnal Of Future Studies

Prasetyo, A., Karinka, U., \& Tehupeiory, P. (2014). Evaluasi Pelatihan dengan Metode Kirkpatrick Analysis. Jurnal Telematika, 9(2), 37.

Putri, R. K., Sari, R. I., Wahyuningsih, R., \& Meikhati, E. (2020). Efek Pandemi Covid 19: Dampak Lonjakan Angka PHK Terhadap Penurunan Perekonomian Di Indonesia. Jurnal Bisnis Manajemen dan Akuntansi 
[ 46] Yohan Fitriadi, dkk / To Maega : Jurnal Pengabdian Masyarakat, Vol. 4; No.1; Februari 2021

(BISMAK), 1(2).

Rohmah, S. N., \& Syari, F. (2020). Adakah Peluang Bisnis di Tengah Kelesuan Perekonomian Akibat Pandemi Coronavirus Covid-19? Buletin Hukum dan Keadilan Adalah, 4(1).

Winanti, P. S. (2020). Perubahan sosial Ekonomi dan Politik akibat Covid 19. Yokyakarta: Gajah Mada University Press.

Yenti Sumarni. (2020). Pandemi Covid-19: Tantangan Ekonomi Dan Bisnis. AlIntaj: Jurnal Ekonomi Dan Perbankan Syariah, 6(2), 46-58.

Zu, Z. Y., Di Jiang, M., Xu, P. P., Chen, W., Ni, Q. Q., Lu, G. M., \& Zhang, L. J. (2020). Coronavirus Disease 2019 (COVID-19): A Perspective from China. Radiology, 200490. 